Utah State University

DigitalCommons@USU

\title{
Spatial variation in the response of tree rings to normal faulting during the Hebgen Lake Earthquake, Southwestern Montana, USA
}

Matthew F. Bekker

Brigham Young University

Follow this and additional works at: https://digitalcommons.usu.edu/wadr

Part of the Environmental Sciences Commons, and the Geophysics and Seismology Commons

\section{Recommended Citation}

Bekker, Matthew F., "Spatial variation in the response of tree rings to normal faulting during the Hebgen Lake Earthquake, Southwestern Montana, USA" (2004). Wasatch Dendroclimatology Research. Paper 12. https://digitalcommons.usu.edu/wadr/12

This Article is brought to you for free and open access by the Research Centers at DigitalCommons@USU. It has been accepted for inclusion in Wasatch Dendroclimatology Research by an authorized administrator of DigitalCommons@USU. For more information, please contact digitalcommons@usu.edu.

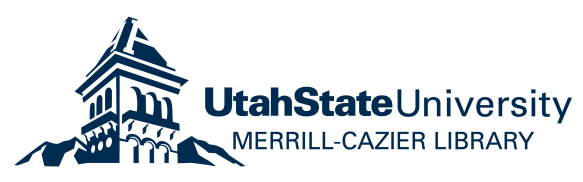




\title{
ORIGINAL ARTICLE
}

\section{Spatial variation in the response of tree rings to normal faulting during the Hebgen Lake Earthquake, Southwestern Montana, USA}

\author{
Matthew F. Bekker* \\ Department of Geography, Brigham Young University, 690 SWKT, Provo, UT 84602, USA
}

Received 12 July 2003; accepted 20 April 2004

\begin{abstract}
Tree rings have frequently been used to identify the effects of earthquakes on forests, but little is known about spatial variation in the response of trees to intraplate normal faulting. This paper documents and describes the effects of tree location (distance from and position above or below the fault scarp), size and age on the response of tree rings to the 1959 magnitude 7.5 Hebgen Lake earthquake, which occurred along a normal fault in the Gallatin National Forest in southwestern Montana. Core samples from 88 trees were collected along nine 100-m transects straddling the Hebgen scarp, and from 28 additional large-diameter trees near the scarp. The most common tree-ring response to the earthquake was a suppression in growth, usually lasting for several years. Among samples from the transects, suppressions were significantly more common below vs. above the scarp, but this pattern was not found among the large tree samples. Distance of trees (within $58 \mathrm{~m}$ ) from the fault scarp had little effect on tree-ring responses. These results illustrate the importance of interactions between tree location and tree size/age in identifying tree-ring responses to earthquakes. Smaller, younger trees required the direct movement of the downthrown block below the scarp to incur sufficient damage to record a suppression, whereas larger, older trees were damaged even on the stationary slope above the scarp. The small effect of distance from the scarp on suppressions suggests that event-response trees may be found further from a fault than previously thought.

(C) 2004 Elsevier GmbH. All rights reserved.
\end{abstract}

Keywords: Earthquake; Hebgen Lake; Dendroseismology; Dendrogeomorphology; Douglas-fir; Disturbance

\section{Introduction}

Major earthquakes frequently cause the loss of human life and property, and represent an important disturbance agent affecting forest structure and function (e.g. Veblen et al., 1992; Allen et al., 1999; Vittoz et al., 2001; Wells et al., 2001). Thus, identifying and quantifying the type and extent of damage from earthquakes, as well as recurrence intervals, is necessary for a complete understanding of forest dynamics and for adequate preparedness for future

\footnotetext{
*Tel.: + 1801422 1961; fax: + 18014220266 .

E-mail address: matthew_bekker@byu.edu (M.F. Bekker).
}

earthquakes. Information about past earthquakes has been obtained using isotopic dating methods, such as ${ }^{14} \mathrm{C}$ (e.g. Sieh and Jahns, 1984) and cosmogenic ${ }^{36} \mathrm{Cl}$ (Zreda and Noller, 1998), as well as historical records. However, the poor resolution of isotopic dates and short length of archival information limit the value of these data sources (Sykes and Nishenko, 1984). Tree-ring records represent a data source with potential to extend information about earthquakes beyond historical records, with annual or subannual precision (Jacoby, 1997). Moreover, tree-ring analysis can provide a quantitative estimate of the magnitude and spatial extent of damage caused by earthquakes (e.g. Allen et al., 1999). 
Tree rings have been used successfully to identify and describe the effects of many different earthquakes on trees throughout the world. Most of these studies have focused on convergent (Jacoby and Ulan, 1983; Sheppard and Jacoby, 1989; Atwater and Yamaguchi, 1991; Veblen et al., 1992; Yadav and Kulieshius, 1992; Kitzberger et al., 1995; Jacoby et al., 1995, 1997; Yamaguchi et al., 1997; Wells et al., 1999, 2001; Allen et al., 1999; Vittoz et al., 2001) and transform (Page, 1970; LaMarche and Wallace, 1972; Wallace and LaMarche, 1979; Meisling and Sieh, 1980; Jacoby et al., 1988; Sheppard and Jacoby, 1989; Lin and Lin, 1998; Schwartz et al., 1998) boundaries between tectonic plates. Few studies have been conducted on tree-ring responses to intraplate faults, where earthquakes are less common, including strike-slip (Stahle et al., 1992; Van Arsdale et al., 1998), reverse (Ruzhich et al., 1982; Stahle et al., 1992; Van Arsdale et al., 1998), and normal (Sheppard and White, 1995; Carrara, 2002) faults.

These studies have illustrated a variety of tree-ring responses to earthquakes. A growth suppression may occur if a tree is damaged directly (i.e. topping, loss of major branches, root damage), or if its nutrient or water supply is decreased. Alternatively, a growth release may occur if neighboring trees are damaged or killed, or through other improvements in site conditions (i.e. altered hydrology). Finally, reaction wood may occur, whereby a tilted tree produces more wood on one side of the bole in order to regain a vertical stance (Scurfield, 1973). Any one or all of these indicators could occur in response to a given earthquake, or even in different areas along the same fault type. Thus, the results of one study may not be directly applicable to another (Sheppard and White, 1995), and an adequate sample size is vital to capturing the range of responses (Butler et al., 1987).

Most previous studies of tree-ring responses to earthquakes have focused on specific "event-response" trees (Shroder, 1980; Shroder and Butler, 1987), located within a few meters of the fault. While this concept is of obvious value, strictly focusing on the most clearly or heavily impacted areas does not allow an assessment of the extent of damage, or of spatial variation in responses to the earthquake. Although a few studies (e.g. Kitzberger et al., 1995; Vittoz et al., 2001; Wells et al., 2001) have documented spatial variation in the effects of earthquakes, they were all focused on plate boundaries, and were primarily concerned with identifying variation in responses among trees on different landforms or substrate types.

This paper analyzes spatial variation in the response of tree rings to the 1959 Hebgen Lake earthquake along the Hebgen scarp, a normal fault located in southwestern Montana. Carrara (2002) analyzed 16 trees within the Cabin Creek alluvial fan along this same scarp, and found various tree-ring responses to the earthquake, but did not examine spatial variation in these responses. This paper builds upon this and other previous studies by explicitly documenting and describing the effects of tree location (distance from and position above or below the scarp), age and size on the response of tree rings to the earthquake.

\section{Background and study area}

The magnitude 7.5 (Doser, 1985; Savage et al., 1993) Hebgen Lake earthquake occurred on August 17, 1959. The epicenter of the quake was located just west of the border of Yellowstone National Park, approximately one mile northeast of Hebgen Lake (Steinbrugge and Cloud, 1962; Witkind et al., 1962) (Fig. 1). The earthquake triggered the massive Madison rockslide, which overran a campground, killing 26 people, and dammed the Madison River, creating Earthquake Lake. Several fault scarps were also created by the quake, including the Hebgen scarp, which runs roughly northwest-southeast along the north shore of Hebgen Lake. Along faults with vertical movement (dip-slip), either block may be thrust upward (reverse fault) or dropped down (normal fault). Surveys and geologic data indicate that the bedrock beneath Hebgen Lake warped and rotated, dropping the north side of the valley more than $6 \mathrm{~m}$ and creating the Hebgen scarp (Fig. 2; Steinbrugge and Cloud, 1962; Witkind et al., 1962).

Near the point where Cabin Creek crosses the scarp, the US Forest Service established an interpretive site at the location of a former campground, which allows easy access to the scarp. Sampling for this study was focused approximately $200 \mathrm{~m}$ southeast of this site in order to

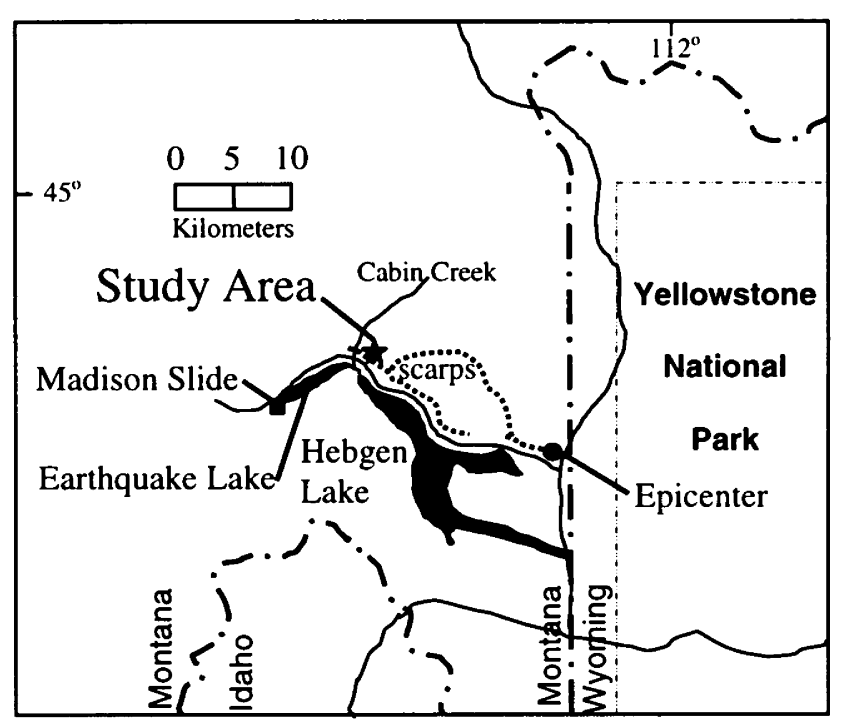

Fig. 1. Location of study area, Hebgen fault scarp, southwestern Montana. 


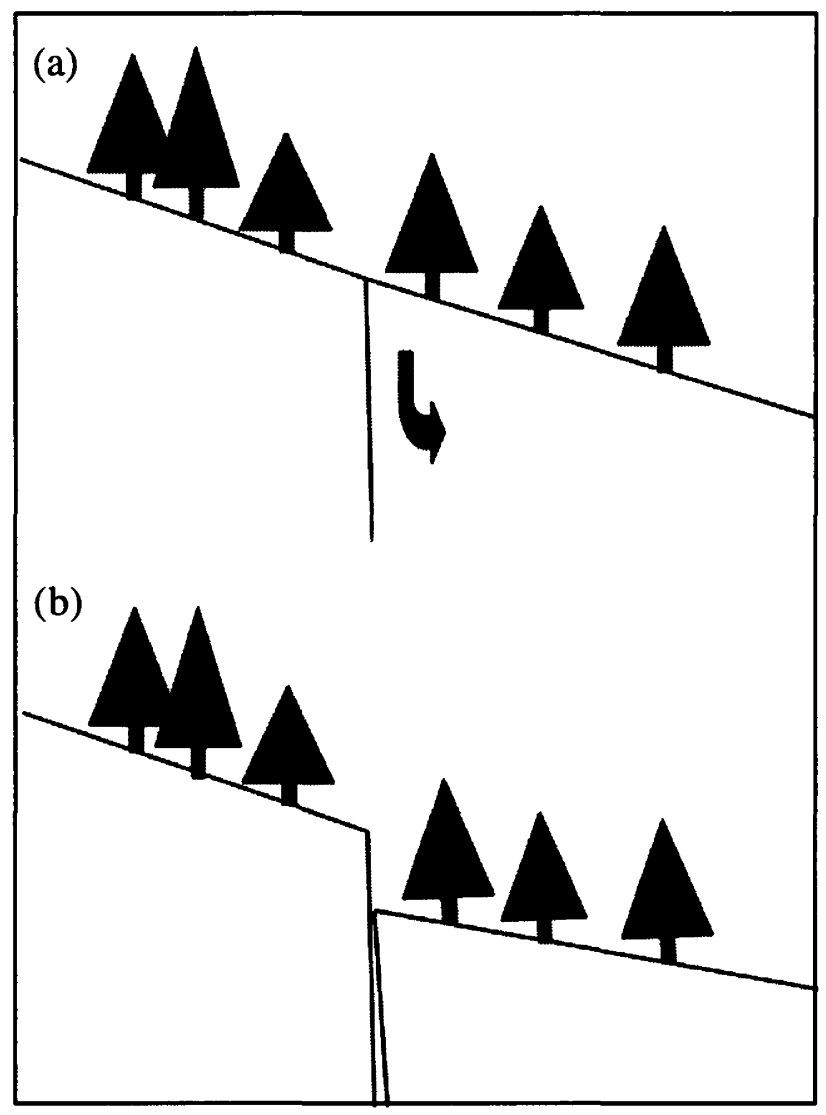

Fig. 2. Diagram illustrating movement of land blocks adjacent to the Hebgen fault before (a), and after (b) the 1959 Hebgen Lake earthquake. The lower slope and valley floor dropped and rotated, exposing the Hebgen scarp.

avoid human influence (e.g. hiking trails, powerlines, etc.). The height of the scarp in this area varies from a few meters to up to $6 \mathrm{~m}$. The scarp face was near-vertical shortly after the quake, but reached its present angle of about $40^{\circ}$ within 20 years (Wallace, 1980). Forests in the area are dominated by Rocky Mountain Douglas-fir (Pseudotsuga menziesii var. glauca (Beissn.) Franco), with some limber pine (Pinus flexilis James) and Engelmann spruce (Picea Engelmannii Parry ex Engelm.).

\section{Methods}

The point-centered quarter technique (Cottam and Curtis, 1956) was used to investigate the effect of distance from the scarp and position above or below the scarp. Nine transects were established perpendicular to the scarp, each extending $50 \mathrm{~m}$ above and below the scarp. Sample points along each transect were established at 5, 20, 35 and $50 \mathrm{~m}$ above and below the scarp.
The nearest tree $(\geqslant 4 \mathrm{~cm}$ diameter at breast height, $\mathrm{DBH}$ ) to each point within a $7.5 \mathrm{~m}$ radius (to avoid including trees located in other sample points) was identified, and the species, DBH, and height category (understory, subcanopy, or canopy) of each tree was recorded. At each sample point, two trees were cored (always in the same two quadrants) at $30 \mathrm{~cm}$ from the ground, on the upslope side of the tree.

In addition to these sample transects, 28 largediameter trees located near the scarp were also sampled. The species, DBH, distance from and position above or below the scarp was also recorded for each tree. In order to determine differences in the response of trees along different radii, two cores, one on the upslope and one on the downslope side of the tree, were taken from each tree approximately $1.4 \mathrm{~m}$ from the ground.

The samples were dried, mounted, sanded with successively finer grits of sandpaper to American National Standards Institute 600 grit $(13.0-16.0 \mu \mathrm{m})$, and polished with very fine steel wool and $9 \mu \mathrm{m}$ finishing paper. The samples were then crossdated (Stokes and Smiley, 1968) under a binocular microscope, and the annual rings were measured to the nearest $0.001 \mathrm{~mm}$.

All samples were analyzed for evidence of response to the earthquake, including suppressions and releases, and the samples from large trees were also analyzed for evidence of reaction wood. Suppressions were defined based on the width of individual rings in comparison with the average ring width for the previous 5 years. Because the earthquake occurred in mid-August, 1959, most trees would have completed their growth for the year at the time of the earthquake. Thus, the years 1955-1959 were used as the base for suppressions. Major suppressions were defined as ring widths $\leqslant 50 \%$ of the 1955-1959 average, and minor suppressions as ring widths $\leqslant 75 \%$ of the $1955-1959$ average. Because suppressions are a result of direct damage to trees, they were only considered to be related to the earthquake if they were initiated immediately after the event (i.e. 1960). A tree was considered to have recovered from a suppression only if at least two rings were wider than the established thresholds.

In contrast to suppressions, growth releases may not begin until a few years after a disturbance (Sheppard and Jacoby, 1989; Kitzberger et al., 1995; Carrara, 2002). This delayed response may be due to the gradual death of injured neighboring trees, or may reflect the time needed for a tree to take advantage of a gap, or to recover from injury itself. For this study, growth releases were defined as periods of growth with ring widths at least $150 \%$ (200\% for "major" releases) of the average width of the 1955-1959 rings, which were initiated within 5 years of the earthquake (i.e. 1964). As with suppressions, a release was considered to have ended if at least two rings were narrower than this $150 \%$ threshold. 


\section{Results}

Core samples from 78 trees (all Douglas-fir except for one limber pine) in the transects contained enough rings to record a response to the earthquake. Of these, 41 were located above the scarp and 37 below. Growth suppression was the most common response to the earthquake, but $59 \%(N=22)$ of trees below the scarp recorded a suppression, compared with only $24 \%(N=10)$ of trees above $\left(P<0.05 \chi^{2}\right)$. The difference in magnitude and duration of suppressions above vs. below the scarp was even greater (Fig. 3). Below the scarp, 13 major suppressions were recorded, compared with only two above the scarp $\left(P<0.01 \chi^{2}\right)$, and major suppressions were also longer in duration below the scarp (up to 12 years) than above the scarp (up to 6 years).

Although the above- vs. below-scarp pattern of releases was opposite than that of suppressions (four releases above compared with two releases below), this difference was not significant $\left(P>0.05 \chi^{2}\right)$. Nevertheless, the releases were also stronger above the scarp in terms of both magnitude and duration (Fig. 4).

In analyzing the effect of distance from the scarp on response to the earthquake, only suppressions were considered due to the small number of releases recorded. Although the proportion of trees with suppressions generally declined with distance from the scarp (Fig. 5), beyond $25 \mathrm{~m}$ this pattern was much less clear, and even at the furthest point (up to $58 \mathrm{~m}$ ) minor and major suppressions were recorded both above and below the scarp.

Trees in the large tree data set averaged $74 \mathrm{~cm}$ DBH and 259 years, and were significantly larger $(P<0.001$ $t$-test $)$ and older $(P<0.001 t$-test $)$ compared to those in the transects, which averaged $35 \mathrm{~cm} \mathrm{DBH}$ and 140 years.

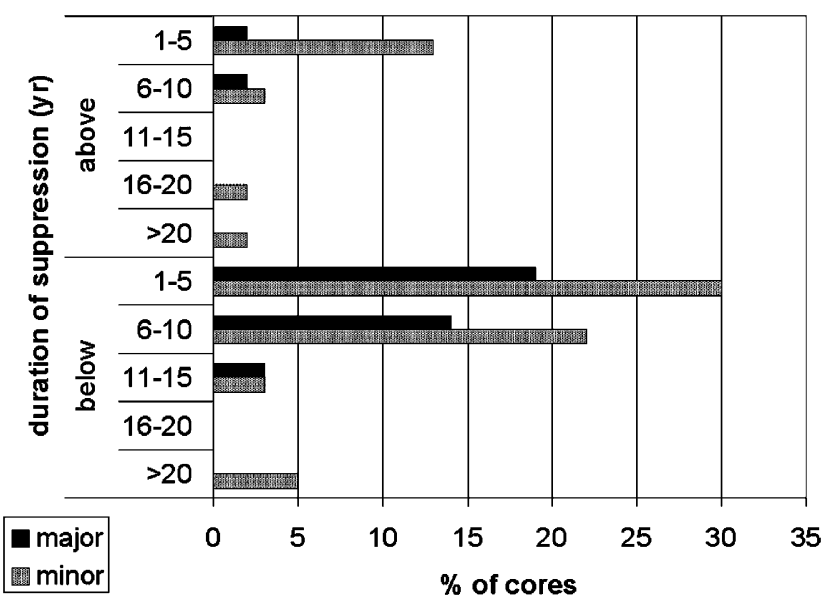

Fig. 3. Duration and magnitude of suppressions in samples from the transect data set above vs. below the scarp. Minor suppressions $=$ ring widths $75 \%$ of average width of 1955-1959 rings. Major suppressions $=$ ring widths $50 \%$ of average width of 1955-1959 rings.

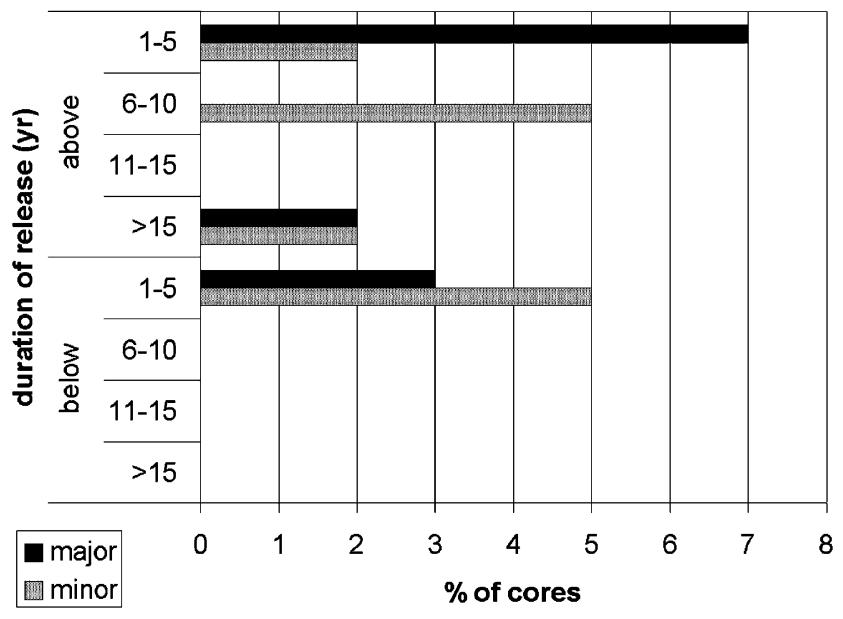

Fig. 4. Duration and magnitude of releases in samples from the transect data set above vs. below the scarp. Minor releases $=$ ring widths $150 \%$ of average width of 1955-1959 rings. Major releases $=$ ring widths $200 \%$ of average width of 1955-1959 rings.

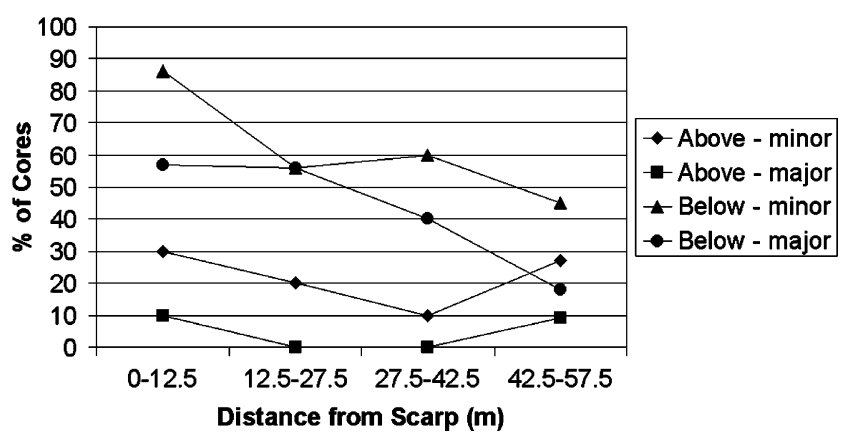

Fig. 5. Proportion of samples from the transect data set exhibiting minor and major suppressions (see Fig. 3) in relation to distance from the scarp.

Of the 28 large trees sampled (all Douglas-fir), 16 were located above the scarp and 12 below. Most samples showed the same general response along both radii (i.e. suppression, release, or no response). No cases of suppression along one radius and release along the other were observed, and no reaction wood was observed in any of the cores. Focusing on the upslope radii in the large trees to facilitate direct comparison with the transect data, $63 \%(n=10)$ of trees above the scarp recorded a suppression, compared to $50 \%(n=6)$ below the scarp, but these differences were not significant $\left(P>0.05 \chi^{2}\right)$. Differences in the duration and magnitude of suppressions above vs. below the scarp (Fig. 6) also were not significant $\left(P>0.05 \chi^{2}\right)$. Finally, there was no relationship between distance from the scarp and duration of suppressions $(P>0.05$, ANOVA). 


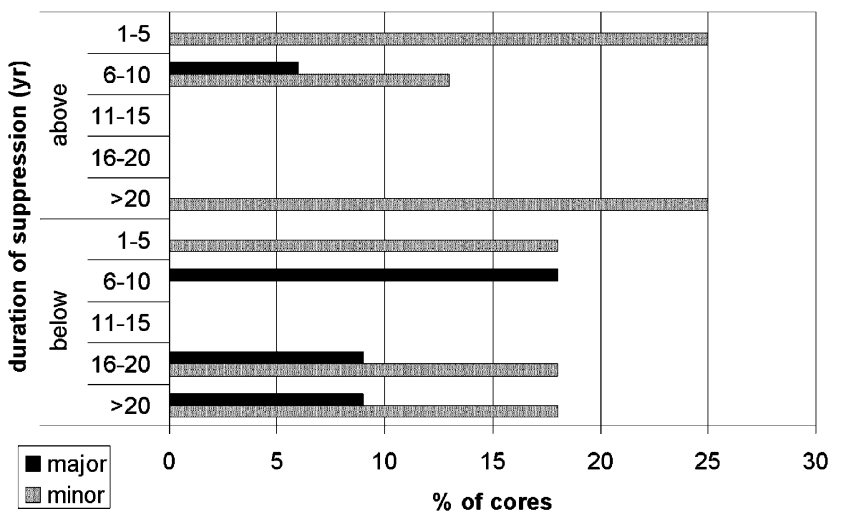

Fig. 6. Duration and magnitude of suppressions (see Fig. 3) in samples (upslope radii only) from the large tree data set above vs. below the scarp.

\section{Discussion}

The transect data illustrate that damage to trees below the scarp was more common and more severe than above the scarp. This pattern is easily explained by considering that trees located below the scarp would have experienced the abrupt movement of the land underneath them, while those above the scarp were only affected by shaking associated with the earthquake (see Fig. 2). This drop in the land surface below the scarp could have damaged trees in several ways, including topping, breakage of major branches, root damage, and altered hydrology. Given that external evidence of damage (i.e. topped or tilted trees) was very rare along this portion of the scarp, and that rates of recovery were variable, root damage seems to be the most likely cause of suppressed growth.

The observation of growth suppressions in the large trees regardless of their position above or below the scarp suggests that tree size and age are also important factors determining tree-ring responses to earthquakes. Larger trees may have more extensive root systems that are more likely to be damaged, or may be more susceptible to topping or loss of major branches (especially taller trees). Moreover, because these trees are older, they may be less able to recover from such damage. These results have important implications for attempts to use tree rings to identify previous earthquakes. A given tree may be large and/or old enough to respond to and record a modern or historic earthquake, but may have been resistant to damage from a prehistoric event due to its smaller stature or younger age. It should also be recognized that a young tree may record a different type of response (e.g. release in response to damage to a canopy tree) than an old one.

The small effect of distance for both transect data and big trees also has important implications for attempts to identify tree-ring responses to earthquakes. Although most previous studies have suggested that samples taken to identify damage from earthquakes should be located within a few meters of fault lines, no particular distance has been established as a guideline. This study suggests that for movement along a major normal fault, trees may still be damaged at least $58 \mathrm{~m}$ away from a scarp. Thus, trees used to construct "control" chronologies for comparison with event-response trees should be chosen carefully, and should be located perhaps more than $100 \mathrm{~m}$ from a scarp. More importantly, these results suggest that event-response trees may be found much further from scarps than previously thought (e.g. Sheppard and White, 1995; Carrara, 2002).

Several similarities may be identified between results of this study and Carrara's (2002) previous analysis of tree-ring responses along the portion of Hebgen scarp located within the Cabin Creek alluvial fan. In both studies, growth suppression was the most common treering response, and these suppressions were of variable duration among samples. However in the Carrara study, suppressions were more common (13 of 16 trees), no differences above vs. below the scarp were noted, and reaction wood was identified in more than half of the samples. The differences between these studies further highlight the importance of location in determining treering response to earthquakes. Most of the samples in the Carrara study were located on an alluvial fan, whereas sampling for this study was conducted $200 \mathrm{~m}$ or more to the southeast, on a more stable slope. Unstable substrates such as alluvial fans and old landslide material increase the susceptibility of trees to damage and tilting (Kitzberger et al., 1995; Vittoz et al., 2001; Wells et al., 2001). In addition, nine of the 16 samples in the Carrara study were located $1 \mathrm{~m}$ or less from the scarp.

Many samples in this study recorded periods of reduced growth from 1917 to the mid-1920s, and again during the 1930s, from which all trees recovered at about the same time. These periods of low growth were also identified by Carrara (2002), and correspond to reduced ring widths in a Douglas-fir chronology collected about $55 \mathrm{~km}$ northeast of the study site (Drew, 1975), as well as reduced spring and summer precipitation (Bradley, 1976) and Yellowstone River streamflow (Graumlich et al., 2003). No evidence of other disturbance agents, such as fire, that could explain the treering responses recorded at the time of the earthquake were observed in the study area.

\section{Conclusions}

This paper illustrates the importance of the interaction of three variables in determining the response of 
tree rings to a normal intraplate fault: position above or below the scarp, distance from the scarp, and size/age of tree. For small to medium-sized trees, responses to the earthquake are most likely to be found below rather than above the scarp. Regardless of tree size, responses are slightly more likely to be found near the scarp rather than further away, but event-response trees may be found much further from faults than previously thought. Further research on spatial variation in treering responses to earthquakes is needed in order to determine the generality of these results and to understand more fully the effects of this disturbance agent on forest structure and function (e.g. Allen et al., 1999).

\section{Acknowledgements}

I thank D. McGinnis for introducing me to this site. S. Bethel, Z. Brandt, R. Heap, A. Laudie, S. Morgan, and T. Smith assisted in the field and D. Bentley, K. Campbell, R. Heap, and M. Smith assisted in the laboratory. Three anonymous reviewers provided helpful comments that greatly improved the manuscript. This research was supported by a Mentoring Environments Grant from Brigham Young University.

\section{References}

Allen RB, Bellingham PJ, Wiser SK. Immediate damage by an earthquake to a temperate montane forest. Ecology 1999;80(2):708-14.

Atwater BF, Yamaguchi DK. Sudden, probably coseismic submergence of Holocene trees and grass in coastal Washington State. Geology 1991;19:706-9.

Bradley RS. Precipitation history of the Rocky Mountain states. Westview Press: Boulder, Colorado; 1976 334pp.

Butler DR, Malanson GP, Oelfke JG. Tree-ring analysis and natural hazard chronologies: minimum sample sizes and index values. Professional Geographer 1987;39(1):41-7.

Carrara PE. Response of Douglas Firs along the fault scarp of the 1959 Hebgen Lake earthquake, southwestern Montana. Northwest Geology 2002;31:54-65.

Cottam G, Curtis JM. The use of distance measures in phytosociological sampling. Ecology 1956;37:451-60.

Doser DJ. Source parameters and faulting processes of the 1959 Hebgen Lake, Montana, earthquake sequence. Journal of Geophysical Research 1985;90:4537-55.

Drew LG editor. Tree-ring chronologies of western America, Washington, Oregon, Idaho, Montana, and Wyoming, vol. 5. Tucson: Laboratory of Tree-Ring Research, University of Arizona; 1975, 45pp.

Graumlich LJ, Pisaric MFJ, Waggoner LA, Littell JS, King JC. Upper Yellowstone River flow and teleconnections with Pacific Basin climate variability during the past three centuries. Climatic Change 2003;59:245-62.
Jacoby GC. Application of tree ring analysis to paleoseismology. Reviews of Geophysics 1997;35(2):109-24.

Jacoby GC, Ulan LD. Tree ring indications of uplift at Ice Cape, Alaska, related to 1899 earthquakes. Journal of Geophysical Research 1983;88:9305-13.

Jacoby GC, Sheppard PR, Sieh KE. Irregular recurrence of large earthquakes along the San Andreas fault: evidence from trees. Science 1988;241:196-8.

Jacoby GC, Carver G, Wagner W. Trees and herbs killed by an earthquake $\sim 300$ yr ago at Humbolt Bay, California. Geology 1995;23(1):77-80.

Jacoby GC, Bunker DE, Benson BE. Tree-ring evidence for an A.D. 1700 Cascadia earthquake in Washington and northern Oregon. Geology 1997;25:999-1002.

Kitzberger T, Veblen TT, Villalba R. Tectonic influences on tree growth in northern Patagonia, Argentina: the roles of substrate stability and climatic variation. Canadian Journal of Forest Research 1995;25:1684-96.

LaMarche VC, Wallace RE. Evaluation of effects on trees of past movements on the San Andreas Fault, northern California. Geological Society of America Bulletin 1972; 83:2665-76.

Lin A, Lin S. Tree damage and surface displacement: the $1931 \mathrm{~m}$ 8.0 Fuyun earthquake. The Journal of Geology 1998;106:751-7.

Meisling KE, Sieh KE. Disturbance of trees by the 1857 Fort Tejon earthquake, California. Journal of Geophysical Research 1980;85(B6):3225-38.

Page R. Dating episodes of faulting from tree rings: effects of the 1958 rupture of the Fairweather Fault on tree growth. Geological Society of America Bulletin 1970;81:3085-94.

Ruzhich VV, San'kov VA, Dneprovskii YI. The dendrochronological dating of seismogenic ruptures in the Stanovoi Highland. Soviet Geology and Geophysics 1982;23(8): $57-63$.

Savage JC, Lisowski M, Prescott WH, Pitt AM. Deformation from 1973 to 1987 in the epicentral area of the 1959 Hebgen Lake, Montana, earthquake $\left(M_{\mathrm{S}}=7.5\right)$. Journal of Geophysical Research 1993;98:2145-53.

Schwartz DP, Pantosti D, Okamura K, Powers TJ, Hamilton JC. Paleoseismic investigations in the Santa Cruz mountains, California: implications for recurrence of largemagnitude earthquakes on the San Andreas fault. Journal of Geophysical Research-Solid Earth 1998;103(B8): 17985-8001.

Scurfield G. Reaction wood: its structure and function. Science 1973;179:647-55.

Sheppard PR, Jacoby GC. Application of tree-ring analysis to paleoseismology: two case studies. Geology 1989;17:226-9.

Sheppard PR, White LO. Tree-ring responses to the 1978 earthquake at Stephens Pass, northeastern California. Geology 1995;23(2):109-12.

Shroder JF. Dendrogeomorphology: review and new techniques of tree-ring dating. Progress in Physical Geography 1980;9:161-88.

Shroder JF, Butler DR. Tree-ring analysis in the earth sciences. In: Jacoby GC, Hornbeck JW editors. Proceedings of the International Symposium on Ecological Aspects of Tree-Ring Analysis: Palisades. New York: LamontDoherty Geological Observatory; 1987. p. 186-212. 
Sieh KE, Jahns RH. Holocene activity of the San Andreas fault at Wallace Creek, California. Geological Society of America Bulletin 1984;95:883-96.

Stahle DW, Van Arsdale RB, Cleaveland MK. Tectonic signal in baldcypress trees at Reelfoot Lake, Tennessee. Seismological Research Letters 1992;63:439-48.

Steinbrugge KV, Cloud WK. Epicentral intensities and damage in the Hebgen Lake, Montana, earthquake of August 17, 1959. Bulletin of the Seismological Society of America 1962;52(2):181-234.

Stokes MA, Smiley TL. An introduction to tree-ring dating. University of Chicago Press: Chicago; 1968, 73pp.

Sykes LR, Nishenko SP. Probabilities of occurrence of large plate rupturing earthquakes for the San Andreas, San Jacinto, and Imperial faults, California. Journal of Geophysical Research 1984;89:5905-27.

Van Arsdale RB, Stahle DW, Cleaveland MK, Guccione MJ. Earthquake signals in tree-ring data from the New Madrid seismic zone and implications for paleoseismicity. Geology 1998;26(6):515-8.

Veblen TT, Kitzberger T, Lara A. Disturbance and forest dynamics along a transect from Andean rain forest to Patagonian shrubland. Journal of Vegetation Science 1992;3:507-20.

Vittoz P, Stewart GH, Duncan RP. Earthquake impacts in old-growth Nothofagus forest in New Zealand. Journal of Vegetation Science 2001;12:417-26.
Wallace RE. Degradation of the Hebgen Lake fault scarps of 1959. Geology 1980;8:225-9.

Wallace RE, LaMarche VC. Trees as indicators of past movements on the San Andreas fault. Earthquake Information Bulletin 1979;11:127-31.

Wells A, Yetton MD, Duncan RP, Stewart GH. Prehistoric dates of the most recent alpine fault earthquakes, New Zealand. Geology 1999;27(11):995-8.

Wells A, Duncan RP, Stewart GH. Forest dynamics in Westland, New Zealand: the importance of large, infrequent earthquake-induced disturbance. Journal of Ecology 2001;89:1006-18.

Witkind IJ, Myers WB, Hadley JB, Hamilton W, Fraser GD. Geologic features of the earthquake at Hebgen Lake, Montana, August 17, 1959. Bulletin of the Seismological Society of America 1962;52(2):163-80.

Yadav RR, Kulieshius P. Dating of earthquakes: tree ring responses to the catastrophic earthquake of 1887 in AlmaAta, Kazakhstan. The Geographical Journal 1992;158(3): 295-9.

Yamaguchi DK, Atwater BF, Bunker DE, Benson BE, Reid MS. Tree-ring dating the 1700 Cascadia earthquake. Nature 1997;389:922-3.

Zreda M, Noller JS. Ages of prehistoric earthquakes revealed by cosmogenic chlorine-36 in a bedrock fault scarp at Hebgen Lake. Science 1998;282:1097-9. 